\title{
Foucault in Iran: Islamic Revolution after the Enlightenment
}

\author{
Behrooz Ghamari-Tabrizi \\ Minneapolis and London: University of Minnesota \\ Press, 2016. 257 pages.
}

To report history in the making, Michel Foucault travelled to Tehran in 1978. He had a commission from Corriere della sera, the prestigious Italian newspaper, to write a series of articles about the unfolding revolutionary process. He landed in Tehran two days after "Black Friday," during which the army was believed to have massacred 5,000 people. Foucault was impressed by the courage of the undeterred protestors who kept pouring into the streets in de- 
fiance of a powerful regime. These articles, sympathetic to the movement and its leading force, Shi'a Islam, received a scornful response from his secular French colleagues. He was accused of being anti-modern, nihilistic, ignorant, and a man beguiled by a revolutionary effervescence.

After the establishment of the Islamic Republic and the consequent bloody battles leading to the concentration of power in the hands of the militant religious revolutionaries, Foucault's detractors put concerted public pressure upon him to repent for his "mistaken" judgments. This major "French" controversy failed, however, to attract much attention in English-speaking circles until the appearance of Janet Afary and Kevin Anderson's Foucault and Iranian Revolution: Gender and Seduction of Islamism (University of Chicago Press: 2005). Highly critical of Foucault's "romantic" depiction of the revolutionary movement, these two authors also found in his reports an occasion to attack his early, post-structuralist writings, interpreting them as anti-modern. The book's overt critique of Foucault rested upon the intellectual pillar of the Enlightenment discourse, with its teleological and secularist approach to history. Needless to say, Afary and Anderson were also critical of Islam's public role, not only in the revolution but also beyond.

Their book received immediate and wide attention. This was a time when the horror of 9/11 had already produced a powerful voice against Islam, or at least political Islam, in academia. Nonetheless, its reception was mixed. Some applauded its astute depiction of both the character of political Islam and Foucault's faulty interpretation of it, whereas others criticized it for misinterpreting Shi'a Islam, misreading Foucault's oeuvre, or both. There was, however, never an entire book devoted to challenging the authors for the sake of rehabilitating Foucault's reputation until the publication of Behrooz Ghamari-Tabrizi's Foucault in Iran: Islamic Revolution after the Enlightenment.

In the introduction, Ghamari writes that "Foucault's sympathy [for the Iranian revolutionary movement] had nothing to do with a romantic fascination with a premodern world and the pastoral exercise of power. Rather, his enthusiasm was kindled by witnessing a moment of making history outside the purview of a Western teleological schema" (p. 6). Ghamari's defense of Foucault rests upon this pronouncement. But the book is more than a judgment of Foucault and his writings; it is a critique of grand and universal narratives, of binary approaches and teleological views of history.

The book consists of five chapters plus an introduction and a conclusion. The first chapter depicts the major events in the revolution's unfolding drama and challenges the narrative of a "stolen revolution." The author prefaces his main argument by advising against the tendency to conflate the separate 
phases of Iran's oppositional activities, namely, the early reformist and predominantly secular phase and the later revolutionary one. He then argues that from the moment the protest movement assumed a revolutionary character, there was no one other than Ayatollah Khomeini who could legitimately claim its leadership.

In his reports, Foucault often referred to the movement's "political spirituality" and Shi' a Islam's liberatory potential. For this, his detractors accused him of naiveté and ignorance. In their characterization of Islam, they relied on its oppressive laws. Ghamari focuses chapter 2, "How Did Foucault Make Sense of the Iranian Revolution?" on the philosopher-journalist's reflection on the revolutionary movement and its spiritual dimension. He defends Foucault with a two-pronged argument: (1) the form of Islam that informed Foucault's sympathetic references was the potentially transformative mystical/ spiritual manifestation of the religion rather than its authoritarian-legal pronouncements and (2) Foucault's observations and reflections addressed only the revolutionary moment, the moment when dismantling a powerful and repressive regime was within people's reach, and not its still unknown outcomes. In other words, Ghamari asserts, Foucault narratives concerned a time when people could become "historical subjects," humans with agency, rather than being merely "subjects of history." The author delivers a strong and persuasive defense of Foucault in this chapter. But then at the end, he seems to undercut his own argument by conceding, at least partially, to Foucault's critics: He points out the "romantic" strand in Foucault's reports, his inadequate understanding of Iranian society, and his lack of knowledge of Islam's legalistic aspects (pp. 72-74).

For most of the next chapter, "Misrepresenting the Revolution, Misreading Foucault," Ghamari's gaze shifts from Foucault to Afary and Anderson and their binary depiction of the revolution. The general argument has been made in other parts of the book. What makes the chapter interesting, however, is how the author makes his points through three famous revolutionary characters: Khosrow Golesorkhi, a secular Marxist opponent of the regime who was executed in 1973; Ali Shariati, the lay-Islamist theorist; and Ayatollah Khomeini. For example, he uses Golesorkhi's famous speech during his trial to undermine the assumed unbridgeable gap between secular and religious values. He goes over Shariati's texts to show that, unlike what Afary and Anderson claimed, being an Islamist did not automatically make Shariati an intolerant bigot. And finally, he uses Khomeini's case to make the case that Islamists do not necessarily have, politically at least, an unchanging "essence," but that their positions could very well be the product of the dynamic of their circumstances. 
One of the major criticisms of Foucault's writings about Iran was his failure to report on Islam's oppression of women and their March 1979 demonstrations against the imposition of hijab, the most visible tool of this oppression. Chapter 4 begins by reiterating the familiar argument that Islam's "texts" have to be balanced by Muslims" "lived experiences" and that the lived experiences of Iranian women both during and after the revolution, including the above-mentioned demonstrations, tell a different and far more complicated story than the ones offered by Kate Millet, Simone de Beauvoir, and other western feminists. The chapter presents the complicated story of March 1979 effectively, but is a rather weak attempt to rescue Foucault from criticism. As it turns out, Ghamari offers only an implied conjecture that Foucault's silence about women could have been the result of his possible awareness of this complicated story.

Chapter 5 offers a strong, clear, and novel interpretation of the relationship between Foucault's earlier and later writings. Afary and Anderson, along with some others, have argued that in contrast with his earlier "nihilisitc" writings, Foucault paid attention to subjectivity, ethics, and the "care of self" in his later work. In other words, he reconciled his thinking with the Enlightenment movement as a universalistic and "progressivistic" project. Ghamari disagrees. He also boldly asserts that Foucault's later writings, rather than being a repentance for his pro-Islamist sentiments, were actually occasioned by his observations of the revolutionary moment. The political spirituality of its participants allowed Foucault, Ghamari maintains, to contemplate the possibility for both creating ethical selves through resisting the existing power structure and for getting out of the universalistic, rationalistic, and "congealed" contemporary Enlightenment discourse.

Is Foucault in Iran merely a long critical review of another book? Can it claim any value besides challenging Afary and Anderson's treatment of Foucault? It is true that Ghamari's mission appears to be one of rescuing Foucault's reputation by refuting this book's central theme. But this is not where its value ends, for he uses Foucault as a spring board to delve into other choppy waters: the debates over historiography, modernity, secularity, the place of public religion, and in this case, of political Islam. These debates are important not only for academic reasons, but also for their policy implications. And this is where the significance of this book lies. 